\title{
Should the Mass Public Follow Elite Opinion? It Depends ...
}

\section{Citation}

Hochschild, Jennifer L. 2012. "Should the Mass Public Follow Elite Opinion? It Depends..." Critical Review 24, no. 4: 527-543.

\section{Published Version}

doi:10.1080/08913811.2012.788280

\section{Permanent link}

http://nrs.harvard.edu/urn-3:HUL.InstRepos:12363919

\section{Terms of Use}

This article was downloaded from Harvard University's DASH repository, and is made available under the terms and conditions applicable to Open Access Policy Articles, as set forth at http:// nrs.harvard.edu/urn-3:HUL.InstRepos:dash.current.terms-of-use\#OAP

\section{Share Your Story}

The Harvard community has made this article openly available.

Please share how this access benefits you. Submit a story.

\section{Accessibility}


Verso rh: Critical Review Vol. 24, No. 3

Recto rh: Hochschild * Should the Public Follow Elite Opinion?

Jennifer L. Hochschild

\section{SHOULD THE MASS PUBLIC FOLLOW ELITE OPINION?}

IT DEPENDS . .

ABSTRACT: John Zaller's finding that members of the public usually follow the cues of elites may seem normatively disturbing. If true, it might seem to obviate the need for democracy or to show that elites are manipulating the public. However, if it is not always true, we can judge cases of public followership according to independent criteria, such as whether the public's occasional rebellions against elite opinion further liberal democratic or utilitarian purposes. A review of some prominent cases of mass followership and mass divergence from elite opinion suggests that public opinion that is independent of elite leadership is neither an unmitigated good nor an unmitigated problem for a well-ordered polity.

Jennifer L. Hochschild, Department of Government, Harvard University, Cambridge MA 02138, thanks Larry Bartels, Jeffrey Friedman, Nancy Rosenblum, and Ian Shapiro for very helpful comments on an earlier draft. 
Ever since "democracy" became an aspiration rather than an aspersion, political commentators have debated whether the good citizen should follow the precepts of presumably knowledgeable and public spirited leaders, or reject the doctrines of presumably blinkered and self-interested elites. Most of what one needs to know about a writer's position in this debate is captured by the terms leaders and elites. In The Nature and Origins of Mass Opinion (Cambridge University Press, 1992), John Zaller elegantly elides this rhetorical distinction by using the phrase "elite opinion leadership." As that elision suggests, he does not explicitly engage with the question of whether the mass public should follow the lead of elites, whether unified or split until the final three paragraphs of the Epilogue. His mission is different: to explain when, why, and how the masses do in fact follow the lead of elites. The dedication of this issue of Critical Review to a retrospective examination of The Nature and Origins indicates how compellingly Zaller accomplished his mission.

Like much research that seeks objectivity, however, Zaller's analysis does in fact tend toward a particular normative standpoint. That is not a criticism; it is close to inevitable and is, in any case, part of why his argument is so compelling. Zaller himself makes his normative standpoint reasonably clear: his rebuttable presumption is that political or policy elites and substantive experts usually make better choices than does the relatively ignorant and mostly uninterested mass public. That leaves him with a question: "If, as I have implied, only specialists are competent to conduct political debate, why bring the public into it at all? Why not let government policy reflect the preponderant weight of expert opinion?" (331). Zaller offers three possible answers: people have a right to be involved in governance; "political participation is a value in itself"; and - the only thoroughly persuasive answer for Zaller - the citizenry provides a 
necessary check on the government's tendency to go "astray and become ... overbearing or worse" (ibid.).

In short, Zaller is more of a utilitarian than a democrat; in his view, a democratic political system works reasonably well because most of the time, citizens follow the lead of elite opinion leadership and most of the time, elite opinion leadership offers—or, through public debate, eventually comes around to - the right moral or "technical" (empirical) conclusion (331). Without being able to provide here a full empirical or philosophical counterargument, this article questions both of these conclusions. In important cases, citizens do not follow elite opinion leadership, and sometimes the country is better off when they do not do so. ${ }^{1}$

By "better off," I mean that the United States moves closer to the ideal of a liberal democracy. I define a "liberal democracy" (or liberal democratic polity) loosely, since not a great deal is at stake for my argument in any particular definition. Roughly, a liberal democratic polity is one in which governmental institutions and policies are intended to promote for all citizens ${ }^{2}$ individual autonomy, dignity, and a reasonable chance to pursue a good life as one defines it for oneself. Furthermore, governmental institutions and practices must be reasonably effective in achieving that aspiration. The relevant polities are those that Robert Dahl (1971) identified as polyarchies, with the structures and political processes that he outlines. However, all of my examples, like most of Zaller's, come from the United States.

\footnotetext{
${ }^{1}$ Of course, Zaller does not argue that citizens always follow elites' lead or that elites are always right. But as an empirical matter, when elites are mostly unified on a complex policy or political issue, "elite communications shape mass opinion rather than vice versa" (268). And when elites are not unified, the book's analysis focuses entirely on how their divided messages change the opinions of some members of the public. Similarly, The Nature and Origins argues that the development and dissemination of elite opinion in the United States comes surprisingly close to meeting the conditions of "an idealized system of public information" (328). I thank Larry Bartels for clarifying my own argument in relation to Zaller's.

${ }^{2}$ I would say "all residents," but that raises the issue of immigration, which I am ignoring in this essay.
} 
Thus, I am closer than Zaller is to endorsing democracy, or rather liberal democracy, on its own terms. I intend my definition to be broad enough, however, to include cases in which the justification for (not) following elite opinion leadership looks more utilitarian than democratic per se. My central question is whether citizens do and should almost always follow elite opinion, whether for deontological or consequentialist reasons.

\section{A Typology of Citizen Responses to Elite Opinion Leadership}

Consider an array of cases, organized by a two-dimensional model comprising four cells. I assume for all cases that there is a strong enough consensus among opinion leaders so that Zaller would expect most citizens to follow their views, for reasons laid out in chapters 6 and 7 of The Nature and Origins. The model's vertical dimension embodies the empirical question of whether most citizens $d o$ follow the lead of reasonably unified elites; its horizontal dimension expresses the normative question of whether most citizens should follow the lead of reasonably unified elites.

Figure 1: Citizen Responses to Elite Opinion Leadership

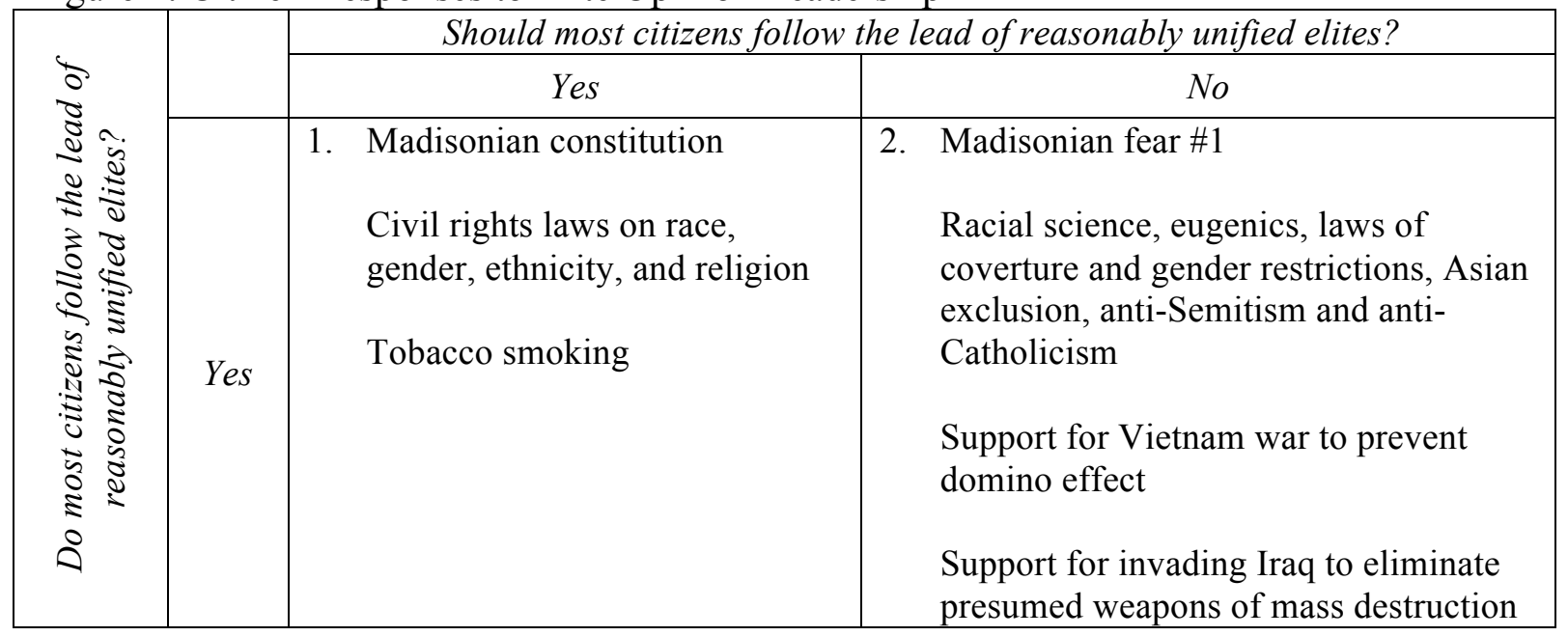




\begin{tabular}{|l|l|l|l|}
\hline \multirow{2}{*}{ No } & $\begin{array}{l}\text { 3. Madisonian fear \#2 } \\
\text { Global warming } \\
\text { Creationism }\end{array}$ & $\begin{array}{l}\text { 4. } \\
\text { Madisonian revolutionaries } \\
\text { Support for President Clinton during } \\
\text { Lewinsky imbroglio }\end{array}$ \\
Origin of Tea Party
\end{tabular}

Cell 1 is yes and yes: citizens follow leaders' opinions as Zaller predicts, and they should do so in a well-ordered liberal democratic polity. As James Madison and others argued in defending the proposed Constitution, a system of elected representatives (or more generally, popularly controlled elite leadership) is designed "to refine and enlarge the public views, by passing them through the medium of a chosen body of citizens, whose wisdom may best discern the true interest of their country, and whose patriotism and love of justice, will be least likely to sacrifice it to temporary or partial considerations" (Hamilton, Jay, and Madison [1787] 1961, 62). ${ }^{3}$ Thus, by following the lead of the elites, citizens will be making the best available choice, whether best is defined in terms of utility (enacting "true interests") or democracy (responding to “public views").

Cell 2 is yes and no: Citizens follow leaders' opinions, as Zaller predicts, but they should not do so in a well-ordered liberal democracy. After all, as Madison and other Framers also recognized, "men of factious tempers, of local prejudices, or of sinister designs, may by intrigue, by corruption or by other means, first obtain the suffrages [i.e., the votes], and then betray the interests of the people" (ibid). In that case, only by rejecting the lead of their representatives will citizens act for the best, with "best" again defined either as democracy or utility.

Cell 3 is no and yes: Citizens do not follow leaders' opinions, but they should do so in a well-ordered liberal democracy. In this case, the empirical regularities of The Nature and Origins

\footnotetext{
${ }^{3}$ Federalist no. 10.
} 
do not hold, or perhaps elite opinion is so divided that citizens cannot follow appropriately - the "two-sided information flows" of Zaller's Chapter 9. Regardless of why citizens do not follow the dominant elite opinion, in this cell they are mistaken not to do so, and the polity suffers as a result.

Finally, cell 4 is no and no: for whatever reason, citizens do not follow the elite consensus, and it is good for the polity and for the furtherance of liberal democracy that they do not. Madison and his fellow Framers were, after all, revolutionaries against an autocratic regime before becoming constitutional designers.

I will examine each cell in turn.

\section{Following the Leader, Fortunately}

Over the past half-century in the United States, cell 1's canonical liberal democratic cases have revolved around race, gender, ethnicity, and religion. I need not rehearse those histories here; roughly speaking, during the 1950s and 1960s, elected and appointed federal officials came to a consensual view that overt racism was unacceptable, as were overt gender, ethnic or nationality, or religious discriminations. Arguably, they were pushed into these positions by what Zaller elsewhere calls "intense policy demanders" (Cohen et al. 2008), by foreign-policy considerations, and by other factors. The crucial point here is that they were not pushed into these positions by mass public opinion.

Over the subsequent few decades, American citizens moved into concurrence; they elected a Catholic president, rejected overt racism and sexism in public opinion surveys or politicians' public comments and behavior, accepted laws to guarantee political equality across groups, and permitted policy measures to reduce overt discrimination, open immigration, and 
compensate for gendered and racialized injustices. Residents of the United States increasingly married across religious lines and, to a lesser degree, across racial and ethnic lines. Americans eventually elected a black president who was the son of an immigrant and whose chief Democratic rival was a woman; as I write, one presidential nominee is not white and one is not Protestant, although both are male.

Americans are, and should be, proud of this history. Although many are rightly angry that the changes remain incomplete and are occasionally reversed, it is almost incontestable that following elites' (and advocates') leads with regard to race, gender, ethnicity, and religion has made the United States a more democratic, liberal, and decent polity.

Another case in cell 1 offers a compelling utilitarian reason for the mass public to follow elite opinion leadership. The Surgeon General first issued a report on the harmful effects of smoking in 1964, with similar reports three more times in the 1960s, eight times in the 1970s, ten times in the 1980s, four times in the 1990s, and five times in the 2000s - that is, almost annually for four decades. Cigarette packages were required to carry warning labels in 1965, and Congress prohibited cigarette ads on television and radio in 1969. Cigarette consumption had risen steadily in the United States since 1900, peaking in 1963 at 4,345 cigarettes per capita annually among adults. At that point it started a steady decline, reaching just under 1,700 in 2006 (a little lower than the level of 1936, and the most recent year for which data are available). The percentage of heavy smokers (more than 24 per day) has declined by 60 percent since 1974 (the first year with data), and decline has been steepest among those with the most education, as Zaller's model would predict (American Lung Association 2011).

Survey data suggest that the reports and the behavioral changes are linked; from 1960 to 1990, the proportion of the public that linked cancer to smoking went from about half to near- 
unanimity. ${ }^{4}$ In short, in important instances, American citizens have followed elite opinion leadership to their own and their country's benefit, as Zaller predicts and prescribes.

\section{Bad Leaders and the Led}

However, it is easy to find cases in cell 2, in which the mass public follows elite consensus but should not do so. One need only consider the first half of the twentieth century. American political and societal leaders created racial science and eugenics, many rejected the presidential candidacy of Al Smith on the basis of his Catholicism, and most accepted, if they did not promote, anti-Semitism and opposition to equal pay and marital rights for women. Members of Congress and California's governors were at the forefront of Chinese and later Japanese exclusion (the latter was known, in fact, as the Gentleman's Agreement); Southern elites promoted Jim Crow legal segregation, and Northern elites treated European immigrants almost as badly. ${ }^{5}$ With very few exceptions among the dominant groups, mass opinion followed elite opinion in all of these domains, to the severe detriment of democracy, liberalism, the economy of the west and south, and general human decency.

Lest we fall into the pleasant delusion of a historical trajectory from the dishonorable past to the praiseworthy present, consider two additional cases in cell 2 . The first is the war in Vietnam, in which "the best and the brightest" insisted for roughly a decade that keeping South Vietnam free from the Vietcong and independent of North Vietnam was in the interests of the United States, the Free World, and the Vietnamese themselves. As the experts saw it, the loss of South Vietnam would produce a domino effect that would threaten liberal democracy and free

\footnotetext{
${ }^{4}$ Unless otherwise noted, all survey data in this essay are available at Roper Center for Public Opinion Research 2012 or at PollingReport.com.

${ }^{5}$ As in the civil-rights and feminist movements of the late twentieth century, the reasons for these elite stances ranged widely from policy considerations to personal values to responses to activist pressures.
} 
trade in Europe, Africa, the Americas, and even the United States (Halberstam 1972).

Americans endorsed this view through the war's buildup and many years of fighting, until elite opinion divided and much of the public came to reject the war and its underlying premises (see The Nature and Origins, chs. 8 and 9). Most Americans now agree that the period in which most elites were unified and the public mostly acquiescent was a moral, political, and substantive disaster.

A final instance of cell 2 is even more recent: justification of the American invasion of Iraq as necessary to eliminate its presumed weapons of mass destruction. On February 5, 2003, then-Secretary of State Colin Powell spoke in the United Nations, reporting the American government's evidence that the Iraqi government was developing weapons of mass destruction. Powell had a reputation as deliberate and cautious and he was known to be skeptical about the virtues of invasion, so his speech was a defining moment both internationally and within the United States. At least three-fifths of American adults reported reading about or hearing Powell's speech, and most found his argument and evidence convincing. More precisely, several survey organizations repeatedly asked a question about support for invasion during the months preceding the sending of troops; three of those series of findings showed an upward spike in support just after Powell's speech. The higher level of support persisted until the invasion occurred several weeks later, at which point the focus of survey questions shifted. ${ }^{6}$

Most generally, in the months before and just after the March invasion, surveys showed that anywhere from two-thirds to nine-tenths of Americans agreed that Iraq had weapons of mass destruction (despite the widely publicized report of the U.N. inspector concluding that it most

\footnotetext{
${ }^{6}$ See Zogby International Poll, 4 January through 15 March 2003 (2 questions, 6 iterations each); Newsweek Poll, 24 October 2002 through 14 March 2003 (1 question, 6 iterations). Both polls can be found at http://www.pollingreport.com/iraq15.htm.
} 
likely did not). Doubts surfaced, however, in the summer of 2003. In July, two-fifths of those surveyed agreed that "the Bush administration deliberately misled the American public about whether Iraq has weapons of mass destruction"; ${ }^{7}$ by November, over half thought that President Bush was lying or "hiding important elements of what he knew." ${ }^{8}$ Elites were also more clearly divided by this point, so the public may have been responding to a two-sided information flow, but the central point is that by following elites' initial lead, Americans endorsed a view that they later concluded was a lie.

That movement from acceptance of a president's lead to disillusionment about his mendacity is surely harmful for a democratic polity. It appears even more harmful when one adds a utilitarian calculation. As early as May 2003, half of the respondents to a poll agreed either that "the war in Iraq was a success but was not worth the cost in U.S. lives and dollars" or "the war in Iraq was not a success." ${ }^{\text {B }}$ B 2011, half or more Americans agreed that the outcome was a "stalemate" or "defeat," that the war was not "morally justified," that the war's cost was harming the U.S. economy, that the war had a "negative effect on life in the United States," or that the invasion and occupation would not prevent civil war and violence in Iraq or terrorism at home. ${ }^{10}$ A question explicitly asking respondents to weigh "the costs to the United States versus the benefits" was repeated six times between January 2009 and November 2011; in five of the six cases, three-fifths or more said "not worth it" (and a majority concurred in the sixth case). ${ }^{11}$

Citizens' weighing of costs against benefits may prove shortsighted; historical judgment is not yet settled on whether the American invasion of Iraq was justified. But the perception of being lied to by the president and thereby tricked into an unnecessary and excessively costly war

\footnotetext{
${ }^{7}$ Gallup, 18-20 July 2003.

${ }^{8}$ CBS News, 10-12 November 2003.

${ }^{9}$ NPR, 27-29 May 2003.

${ }^{10} \mathrm{CNN} /$ ORC poll, 16-18 December 2011.

${ }^{11}$ ABC News/Washington Post Poll.
} 
is damaging to the polity regardless of the war's long-term impact on international relations. At this point, at least, it seems justified to conclude that citizens' acceptance of elites' message that the U.S. must invade Iraq to eliminate weapons of mass destruction was a mistake, from both liberal-democratic and consequentialist perspectives.

\section{The Wayward Public}

Two prominent cases in recent years illustrate both utilitarian and liberal democratic reasons to wish that citizens had followed elites' lead when they did not.

First, the scientific consensus with regard to global warming has been strong and consistent for several decades. The Intergovernmental Panel on Climate Change, created in 1988 by the World Meteorological Organization and the United Nations Environmental Programme, concluded in 2001 that "human activities ... are modifying the concentration of atmospheric constituents ... that absorb or scatter radiant energy.... [M]ost of the observed warming over the last 50 years is likely to have been due to the increase in greenhouse gas concentrations" (McCarthy et al. 2001, 21). That statement was preceded and followed by perhaps dozens of similar ones, with a great deal of concurring media coverage over many years and little dissensus among climatological experts.

Yet only half of the respondents to a $2011 \mathrm{CNN}$ poll agreed that "global warming is a proven fact and is mostly caused by emissions from cars and industrial facilities." ${ }^{12}$ This result is typical; in fact, as scientists' evidence on and warnings about global warming strengthened in the late 2000s, Americans' concurrence with elite views declined. The Gallup Poll has repeatedly

\footnotetext{
${ }^{12}$ Another fifth agreed that global warming is occurring, but attributed it to "natural changes that have nothing to do with emissions from cars and industrial facilities." Roughly a third perceived global warming to be an unproven theory (CNN/ORC International Poll, September 2011).
} 
asked "when the effects of global warming will begin to happen" for many years; the proportion agreeing on "already" rose from 48 percent in 1998 to 61 percent in 2008 and declined back to 49 percent in 2011. The proportion saying "never" rose to 19 percent in $2010 .{ }^{13}$ The American public is much more split than are knowledgeable elites, and the world is likely to pay considerable economic, social, and political costs as a consequence.

Creationism offers a similar case with less obvious but perhaps equally severe harms. The evidence supporting evolutionary theory is as compelling as the evidence on global warming, and evokes the same degree of near-unanimity among scientists. ${ }^{14}$ It has done so for decades. Yet since 1982, a plurality of Gallup poll respondents (nearly half, in fact) have consistently agreed that "God created human beings pretty much in their present form at one time within the last 10,000 years or so." As Zaller's model predicts, Americans with the most education are least likely to be creationists; nevertheless, a quarter of respondents with postgraduate degrees concur that God created humans in their present form relatively recently (Newport 2012).

In a liberal democracy, people have the right to hold any religious belief or none. But creationism becomes problematic for a polity when state boards of education seek to introduce it into public school curricula (see Binder 2004). As of this writing, nine states permit or require critical analysis of evolutionary science. In principle, of course, any scientific theory should be

\footnotetext{
${ }^{13} \mathrm{lbid}$.

${ }^{14}$ As Jeffrey Friedman pointed out in response to an earlier draft, "scientific consensus is often wrong." Afterall, some experts worried about global cooling in the 1970s, experts agreed for decades that homosexuality is a mental disorder or a reversible lifestyle choice, and eugenics was a thoroughly respectable science in the first third of the last centuryCases in cells 2 and 4 provide other examples. I have neither space nor sufficient knowledge to engage here with the question of whether evolutionary theory or warnings about global warming are correct; for my purposes in this article, I assume that they are. Luckily, my argument rests less on the absolute claim that the experts are right in these cases than on the more relative claim that the best evidence strongly supports their claim to correctness, and that promoting the alternatives (creationism or continued reliance on high uses of fossil fuel) could be very costly indeed.
} 
subject to scrutiny, but in practice the intention is generally to introduce religious viewpoints into science classes. As the Supreme Court put it,

We do not imply that a legislature could never require that scientific critiques of prevailing scientific theories be taught. . . Teaching a variety of scientific theories about the origins of humankind to schoolchildren might be validly done with the clear secular intent of enhancing the effectiveness of science instruction. But because the primary purpose of the Creationism Act is to endorse a particular religious doctrine, the Act furthers religion in violation of the Establishment Clause. $^{15}$

Teaching creationism may not be "child abuse" akin to teaching that the earth is flat, as Richard Dawkins (2008, ch. 9) claims. Nevertheless, scientists fear that rejection or ignorance of basic evolutionary theory will inhibit citizens' ability to engage with public concerns ranging from drug development to the combating of climate change. More generally, "there is a real risk of a serious confusion being introduced into our children's minds between what has to do with convictions, beliefs and ideals and what has to do with science, and of the advent of an 'all things are equal' attitude, which may seem appealing and tolerant but is actually disastrous" (Committee on Culture 2007). Even if evolutionary science needs revision, short of a Kuhnian paradigm shift students are educationally harmed if it is displaced by creationism in the classroom. And a liberal democratic polity is harmed by allowing public-school curricula to be shaped by a particular religious conviction. This is a case in which Zaller's model of "elite

\footnotetext{
${ }^{15}$ Edwards v. Aguillard 107 S.Ct. 2573
} 
communications shap[ing] mass opinion rather than vice versa" (268) would be a considerable improvement over the status quo.

\section{The Heroic Public}

Finally, one can identify a few cases of cell 4 , in which citizens reject elite opinion leadership and the polity is better off as a consequence. Zaller himself pointed to the early stages of one instance of non-followership in the striking article, "Monica Lewinsky's Contribution to Political Science." He pointed out that "the bounce in President Clinton's job ratings that occurred in the initial 10 days of the Lewinsky imbroglio may offer as much insight into the dynamics of public opinion as any single event in recent memory. ... It shows ... the importance of political substance, as against media hype, in American politics." In considerable tension with The Nature and Origins, Zaller $(1998,182,186)$ concluded that this case reveals "just how relentlessly the majority of voters can stay focused on the bottom line.... It is possible for public opinion and media opinion to go marching off in opposing directions."

The story changed little over the next year. The media and many political elites focused obsessively on the unfolding Lewinsky story, and from January through September 1998, “Clinton's evaluations on network news averaged 63 percent negative to only 37 percent positive" (Just and Crigler 2000, 188). In the first four days after the news broke, reporters commented that if Clinton "lied ... and obstructed justice, he's going to have to leave town in disgrace"; that "Lewinsky's age and the talk of extramarital relations in the White House threaten to turn the public against the president in a way other cases haven't"; that if the reports are accurate, "his presidency will be in ruins"; that "his presidency is now worth, uh, zip;" and at 
least one commentator asked, "What does President Gore do?" (Kalb 2001, 143, 160, 164, 166, 226).

The public was almost as heavily engaged; by August 1998, 61 percent wished that they "knew less than. .. [they] currently know."16 Americans disapproved of Clinton's sexual activity and his possible perjury, but most did not endorse his removal from office. Twenty-five polls from January 1998 through August 1999 asked (with slight variations in question wording), "If it turns out that President Clinton obstructed justice [OR committed perjury] by encouraging Monica Lewinsky to lie under oath, or by lying under oath himself, what do you think should happen?" In every one of these surveys, fewer than half of the respondents supported impeachment or resignation, with a decline to about two fifths by the end of the period despite continued revelations and elite arguments. According to every survey organization, at least threefifths of those surveyed, and sometimes as high as seven in ten of them, approved Clinton's handling of the presidency throughout the period of revelation, impeachment, and trial. Possibly, as Zaller mplies, the public's materialistic concern for peace and prosperity outweighed their concern about sexual malfeasance or legality An alternative interpretation is that the public saw Clinton's opponents as trying to oust a popular and legitimately elected president before his term of office was complete by any means that they could legally create. . If so, then the failure of most of the public to follow the lead of elite opinion leadership was a signal victory for both liberalism and democracy.

A final cell-4 case to consider is the origin of the Tea Party. Despite its very different political valence from the Clinton/Lewinsky imbroglio, it presents an analytically similar example of the mass public's rejection of elite messages. And it too can be used to show that the public may on occasion be wiser than ostensible leaders.

${ }^{16}$ Gallup/CNN/USA Today, 10-12 August. 
The Tea Party emerged in part through rebellion against Republican as well as Democratic leaders. During the economic crisis of 2008, elites of both parties endorsed emergency measures to forestall a deep depression; from the perspective of radicalized conservatives, both parties were to blame for the ensuing government "takeover" of the freemarket economy. Anger at both parties' leadership persisted even after the 2010 mid-term election.

Tea Partiers did not bask for long in the 2010 afterglow [of a widespread defeat of Democrats]. It was no time to relax and let Republicans in office fall into go-along-to-get-along routines of meeting Democrats halfway.... They would not hear of compromises, and pushed GOP officials to act quickly and unremittingly. .. . Even GOPers supported by Tea Partiers could "disappoint". . . To avoid such betrayals, Tea Partiers [thought they needed to] ... "organize for the long-term to carry the movement into the halls of government.” (Skocpol and Williamson 2012, 4-5)

Clinton's supporters were largely passive in their rejection of elite opinion leadership, while Tea Partiers were energetically active. But both stand against Zaller's conclusion that when elites are reasonably unified in their views, "elite communications shape mass opinion rather than vice versa" (268). Whether the benefits of Tea Party activism will prove to outweigh its costs to the economy remains unclear, although I strongly doubt it. But a movement that galvanized citizens to work even harder to persuade others to share their views and act on them 
through political discourse and electoral mobilization is surely good for democratic governance over the long run.

\section{When Should Citizens Follow Elite Opinion Leadership?}

Thus Zaller's model of public-opinion formation in response to a unified elite message does not always hold. Of course, The Nature and Origins of Mass Opinion does not argue that it will always hold. The empirical question of when and why public opinion deviates from the views of a unified elite is fascinating and important, but digresses from my purpose here. The remaining question for this essay is: when should citizens reject elite opinion leadership?

In principle, the answer is easy: the mass public should join the elite consensus when leaders' assertions are empirically supported and morally justified. ${ }^{17}$ Conversely, the public should not fall in line when leaders' assertions are either empirically unsupported, or morally unjustified, or both.

That simple rule does a surprising amount of normative work. First, it resolves any ambivalence about whether a democratic polity should permit majority opinion to mandate creationism in public schools or to abjure international treaties or other policies designed to reduce global warming. At least given the present state of scientific knowledge, the evidentiary bases for both evolution and climate change are very strong and the costs of ignoring both are high. So elites who foster public activity based on false empirical premises can fairly be blamed for causing harm, and the public can fairly be challenged to accept the scientific consensus.

Democratic governance is not enhanced by denying the laws of nature.

\footnotetext{
${ }^{17}$ Moral justification is another term needing careful definition in many contexts, but not here. By it I mean actions that foster liberal democracy - that is, actions that promote individual autonomy, dignity, and a reasonable chance to pursue a good life as one defines it, for all citizens. Political actors will, of course, dispute just what those actions are; nevertheless, in a decent society, the underlying principle of liberal democracy sets boundaries around Zaller's dominant and countervalent messages.
} 
For the same reason, citizens were right on utilitarian grounds to follow leaders' insistence that smoking is dangerous to health. Democratic governance might be harmed by an outright ban on smoking, but citizens are surely better off if they accept the views of elected and appointed officials in this case and change their behavior accordingly.

Second, for the opposite reason, the rule also provides guidance on the Clinton/Lewinsky case, at least for people who endorse a broadly center-left perspective. The contention that Clinton committed perjury or encouraged Lewinsky to do so remains disputed as an empirical matter. But the more important issue in this case is whether the claim that he should leave or be removed from office is morally justified. In my view, the answer is no. "Moral" here is collective, not individual: Given that most other Americans shared my view over a long period of time and in the face of extensive media attention to the opposite position, retaining Clinton in office promoted the well-being of Americans and the integrity of the electoral process much more than removing him would have done.

The simple rule for when the mass public should follow elites' lead also resolves any hesitation with regard to views and actions on race, ethnicity, gender, and religion. Ignoring the vast array of caveats and complexities, citizens should not have followed elite opinion leadership in the era of Jim Crow, gender and religious discrimination, and immigrant exclusion—and they should have followed elite opinion leadership in the era of civil rights, admission of immigrants, feminism, and religious tolerance.

The remaining three cases are more difficult to judge, since the simple rule does not suffice. Most people now agree that intervention in Vietnam was not needed to protect the United States' international interests, and that interfering in a small country's civil war was normatively wrong. But the judgment about whether elites were empirically correct and morally 
justified in getting the United States involved depends too much on the outcome of the conflict; if the United States had won the Vietnam War or if Communism had continued to endanger liberal democratic polities, many people might now view supporters' empirical and normative claims with more favor. The need for hindsight in order to determine whether the masses should have followed elites' lead makes one's normative stance uneasily hostage to fortune.

Similarly we now know that government leaders were wrong when they claimed that Iraq had weapons of mass destruction in early 2003. There is also good evidence that elites were at best injudicious and at worst mendacious in making that claim, and that they ignored counterevidence or the value of waiting until the United Nations' inspection was complete. But the moral worth of the invasion nonetheless remains a legitimate point of dispute. I share the dominant public view that the war was too costly in many ways for both the United States and Iraq, and that it damaged democratic governance (not least by being fought largely through hired mercenaries rather than a drafted citizenry). But if Iraq ends up with a functioning democratic government and leaders less vicious than Saddam Hussein, the invasion might in retrospect come to seem worthwhile.

Finally, the Tea Partiers' political energy, ideological earnestness, and organizational skills contribute to democratic governance. But again, whether their rebellion against political leadership as usual benefits the United States depends considerably on the outcome of their choices and activities. If racism, xenophobia, class-based selfishness, or religious intolerance outweigh commitment to private enterprise and personal responsibility, or if ideological earnestness devolves into intransigence and sulkiness, then this popular uprising will prove illiberal and too costly in utilitarian terms. In that case, the Tea Party will not belong in cell 4, in which citizens reject the elite consensus and thereby enhance liberal democracy. 
The Nature and Origins of Mass Opinion is one of the (few?) books that should make us proud to be political scientists. Its prose is clear, its arguments elegant, and its evidence compelling. An unintended virtue is that it leads the reader into difficult and important normative questions that the author himself mostly eschews. When should the mass public accept consensual elite opinion leadership? How should citizens adjudicate between dominant and countervalent elite messages? How can more citizens be brought to think about those questions, and does the Receive-AcceptSample model simply describe or also undermine the belief that citizens ought to be the final decision makers?

The Nature and Origins does not explicitly challenge core precepts of democratic theory, but it certainly provides ammunition for one who wishes to do so. Whether citizens' occasional rebellion against elite opinion leadership should make us nervous, as Zaller implies, or gratified remains an open question.

\section{REFERENCES}

American Lung Association. 2011. Trends in Tobacco Use. Washington, D.C.: American Lung Association.

Binder, Amy. 2004. Contentious Curricula: Afrocentrism and Creationism in American Public Schools. Princeton: Princeton University Press.

Cohen, Marty, David Karol, Hans Noel, and John Zaller. 2008. The Party Decides: Presidential Nominations Before and After Reform. Chicago: University of Chicago Press. 
Committee on Culture, Science and Education, Parliamentary Assembly. 2007. "The Dangers of Creationism in Education." http://assembly.coe.int/main.asp?link=/documents/workingdocs/doc07/edoc11297.htm.

Dahl, Robert. 1971. Polyarchy: Participation and Opposition. New Haven, Conn.: Yale University Press. Dawkins, Richard. 2008. The God Delusion. New York: Mariner Books.

Halberstam, David. 1972. The Best and the Brightest. New York: Random House.

Hamilton, Alexander, John Jay, and James Madison. [1787] 1961. The Federalist, ed. Jacob Cooke. Middletown, Conn.: Wesleyan University Press.

Just, Marion, and Ann Crigler. 2000. "Leadership Image-Building: After Clinton and Watergate." Political Psychology 21(1): 179-98.

Kalb, Marvin. 2001. One Scandalous Story: Clinton, Lewinsky, and Thirteen Days That Tarnished American Journalism. New York: Free Press.

McCarthy, J. J. et al. 2001. Climate Change 2001: Impacts, Adaptation, and Vulnerability. Cambridge: Cambridge University Press.

Newport, Frank. 2012. "In U.S., 46\% Hold Creationist View of Human Origins." Gallup Politics http://www.gallup.com/poll/155003/Hold-Creationist-View-Human-Origins.aspx.

Roper Center for Public Opinion Research. 2012. "Ipoll." http://www.ropercenter.uconn.edu/.

Saad, Lydia. 2012. "In U.S., Global Warming Views Steady Despite Warm Weather." Gallup Politics http://www.gallup.com/poll/153608/Global-Warming-Views-Steady-Despite-Warm-Winter.aspx.

Skocpol, Theda, and Vanessa Williamson. 2012. The Tea Party and the Remaking of Republican Conservatism. New York: Oxford University Press.

Zaller, John R. 1992. The Nature and Origins of Mass Opinion. New York: Cambridge University Press. Zaller, John. 1998. "Monica Lewinsky's Contribution to Political Science." PS: Political Science \& Politics 31(2): 182-89. 